\title{
Effect of Planting Dislances on Shaded Coffee Yield in Puerto Rico'
}

\author{
S. J. Rodrínez, R. Bosque Lugo, R. Pérez-l'érez, and \\ A. Blorales B/uñoz
}

\section{INTRODUCTION}

Coftec is one of the main cash crops of Pucrio Rico. In the coffen growing area, located in the Wost Central mountainous part of the Island al elevat(ions varying from 500 feet to around 3,000 feet above sea level; highly lenched latowols with slopes above 30 perent are juredominant.

Statistics show an average production of 200 pounds of market cofiec per cuerdat, for an eslinated area of 160,000 cuerdas. The yields are very low as comprared with other coffee-producing countric's such as Hawaii, El Salvador, and Brazil, and also with the few inteosively managed coffec groves in l'uerto Rico.

The results of field trials involving different planting distances in coffeeproducing countries have been adec(ualely covered by Wellman (6) ${ }^{4}$. Longrange experiments have shown favorable results of close planting distances at the beginning of the trials. In the long run, the "lose planting distaness will rectuire thiming to facilitale cultural pructices. bartors such as soil fertility, clevation, slope, temunctulurc, dainfall, and pruning system must be considered when deciding upon a suitable planting distance. Noreover, the incidence of discuses and insect pests must be taken inlo ronsideration when selereting a planting distance, nol only because of difficully in controlling the pests, but also to allow for the factors that might favor the spread of a discase or insect attack, A reenent report by Beaumont and Fukumag $(/)$ of an experiment "arried on all liona, showed no statistical differences among thee planting distances in rows 8 feet apart.

Medina (3), reported that a single Robusta coffee tree planted in a "covit" is with only one vertical produced as much coffee ats a tree pruned to leave four vericisls, or l wo and four trees per coval pruned to four vertirals as a whole.

Soint contribution of the (iurabo and Adjuntas Substations.

3 Asociate Florticulturist, (iurabo Substation; Assistant Agronomist in Charge, Adjunt:k, substation; Arsistant Entomologist, Adjuntas Substation, i.e. the Coffer Substation; Rescarel, Assistant in Agronomy, Adjuntas Substation; Agricultural Bxperiment Station, Cnivexsity of Puerto Rico, Rín Piedras, P.R. The assistaner of other persomuch of the colfee substation is apprecialed.

${ }^{3}$ A ruerth is equivalent to 0.97 of an aese.

Italic mumbers in parentheses refer to literature Cited, p. 86.

"Cova" is a system of coffec planting in general use in Brazil and Angola in which 1 to 4 trees are planted per hole 1 foot apart. 
This paper summarizes an experinent conducted at the Coftee Substalion of the Agricultumal Experiment station, Adjuntas, at which different; planting distances were lested as to eoflee yield response.

\section{P'ROCLI) RI:}

The experiment was loented at the Coffee Substition lium, Adjuntas, in the heart of the coffee-growing area of the Island. At the site, at an elevation of around 2,000 foet above sea level, the soil was a highly leached latosol Alonso clay with fairly goor strueture.

Amual ramfall is approximately 70 to 80 inches with two peaks in the rainfall paltem during the months of April and Iay and August and September. Daily temperatures fluc(uate from a minimum of $60^{\circ} \mathrm{I}$. to a maximum of $85^{\circ} \%$.

TaBLe 1.- Plonting distances in the trial showing number of colfes trees per acre for each trealment

\begin{tabular}{|c|c|c|c|}
\hline Treatment & Planting distances in feet & System & Trees per acre \\
\hline A & $3 \times 3 \times 9$ & Double hedge & 2,410 \\
\hline 13 & $3 \times 6$ & Single hedge & 2,419 \\
\hline C & $3 \times 9$ & do. & 1,613 \\
\hline 1) & $3 \times 12$ & do. & 1,210 \\
\hline Is & $6 \times 6$ & de. & 1,210 \\
\hline li & $(i \times 9$ & dio. & 806 \\
\hline 6 & (j) $\times 12$ & do. & 605 \\
\hline II & $9 \times 9$ & do. & 5,38 \\
\hline r & $9 \times 12$ & do. & 40,3 \\
\hline$J$ & $12 \times 12$ & dn. & 302 \\
\hline
\end{tabular}

Uniform I-ycar-old coffee seedlings of the Boubon variety ( $C$. Aralica L. vim. Bourbon Rdz. and Choussy) were used. The seedlings were transplanted from the nursery to the field with an earth-ball to reduce root damage. The scedlings were planted at the same depth as they were in the nursery. The system followed as much as possible a square pattern for each plot. The population in a $36 \times 36$-foot plot varied from a maximum of 72 to a minimum of 12 trees per plot (table 1 ). The distribution lollowed a paired-plot design as recornmended by Capó (2), with 9 replications.

The shade consisted of mixed leguminous trees and banumas. If was prumed annually to permit around 30 to 50 percent of sunlight: A $9 \cdot 10-5$ fertilizer was applied to each plot at the rate of 12 hundredweights per acre in two split applications.

Fertilizer was applied immediately after the picking season and the second application during the summer months. 'The fertilizer was broadcast around the trees and plot area. 
Weeding was done as a general rule fwice a year, although sometimes more than wo weedings were performed in the year, depending on the weed growth. feat miner and other insects were controlled with a mixture of $1 \frac{1}{2}$ pound of 15 -pereent Parathion and 2 quarts of 15 -pereent Dieldrin per acre, as recommentad by the Enlomology Department.

Coffee was picked during the hatvesting seatson rogularly every 15 days. Berries were weighed immedintely after pieking in the feld. During the last crop, datat on the time required to piek each plot on each picking date wore gathered. Datit were changed 10 market coffee based on a 5:1 ratio.

The 7-year data were analyzed statistically by analysis of variance, and a colrelation analysis on the time required for picking each plot was performed on the last-year arop.

I'LBLE 2.-Unadjusted annual mean production of market coffee in hundredweights per acre, as related to planting distance, 1956-62

\begin{tabular}{|c|c|c|c|c|c|c|c|}
\hline Treatment & 1950 & 19) 57 & 1)58 & 1959 & 1960 & 1961 & 1962 \\
\hline$A$ & 1.33 & 14.40 & 12.84 & 12.42 & 12.50 & 10.18 & 10.71 \\
\hline B & 1.47 & 16.07 & 19.26 & 17.36 & 16.03 & 12.05 & 13.30 \\
\hline C & 1.32 & 10.96 & 10.09 & 12.20 & 11.58 & 10.18 & 10.70 \\
\hline 1) &.$\$ 1$ & 6.26 & 7.19 & 8.81 & 8.65 & 0.02 & 9.02 \\
\hline Is & .75 & 10.72 & 11.08 & 13.14 & 12.32 & 12.70 & 13.01 \\
\hline $\mathrm{I}^{r}$ & .45 & 6.78 & 5.69 & 7.01 & 8.45 & 8.28 & 9.21 \\
\hline Ci & .50 & 3.04 & 4.75 & 4.71 & 7.09 & 6.48 & 8.78 \\
\hline II & .27 & 3.00 & 5.58 & 7.02 & 8.27 & 8.02 & 8.09 \\
\hline I & .08 & 2.50 & 3.54 & 4.84 & 6.18 & 7.35 & 8.17 \\
\hline$J$ & .14 & 1.30 & 2.28 & 3.04 & 3.91 & 4.45 & 1.73 \\
\hline
\end{tabular}

\section{RESULTS AND DISCUSSION}

The madjusted annual mean yields are presented in table 2. As expeoted, trees under treatments $A$ and $B$ with a higher population per unil area reached their peak production, within the 7-year experimental period, sooner than the trees in all other treatments. This corroborates previous information summarized by Wellman (3). Nevertheless, the drop in yield was not as severe as expected. Even in treatment B, in which the maximum yield was observed in the third year, the drop was not sharp. The drop was steady until the sixth crop and then there was an increase in yield.

The overall effect of planting distances is presented in table 3 . The results showed that a planting distance of $3 \times 6$ feet (treatment $B$ ) was the best suited for planting coffee in Puerto Rico. This treatment outyielded significantly the rest of the treatments. Treatinents A (3 $33 \times 9$ feet double hedge), $\mathrm{C}(3 \times 9 \mathrm{feel})$ and $\mathrm{E}(6 \times 6 \mathrm{fect})$ followed treatment $\mathrm{B}$. The three 
treatments signifieanty outyidded treatments D $(3 \times 12$ feet $)$, is $(6 \times 9)$

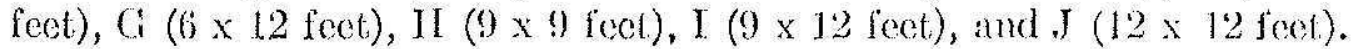
Treatments 1$)$ and $F$ were superior to treatment $J$; however, traiments $\mathrm{G}, \mathrm{H}$, and I did not signifieantly outyield treatment, J. An inerense in distance between trees in the lines brought about a decroase in yjeld. This fact can be clearly established in the comparison of treatments B, C, D and E, F, C. By comparing treatment: B, E, and $\mathrm{G}$; C, F, and $\mathrm{H}$; and D, $\mathrm{B}$, and I as separate groups, we can see that an increase in distances among lines, without a change in distances between trees reduced yields.

A clear explanation of the results camot be triced to a simple increase of the population per unit-area. Treatments $A$ and 13 had the same number

TABbe 3,- Combined adjusted mean production of market roffee yields for ti crops, as reluted to planting distance

\begin{tabular}{|c|c|c|c|c|}
\hline Treatment & Planting distance in feet & frees per acre & \multicolumn{2}{|c|}{ Hundredweights per acre } \\
\hline A & $3 \times 3 \times 9$ & 2,419 & 12.38 & b \\
\hline$B$ & $3 \times 6$ & 2,419 & $15.78:$ & \\
\hline C & $3 \times 9$ & 1,613 & 11.02 & b \\
\hline J) & $3 \times 12$ & 1,210 & 8.17 & $c$ \\
\hline $\mathrm{E}$ & $6 \times 6$ & 1,210 & 11.74 & b \\
\hline F & $6 \times 9$ & 800 & 7.55 & $c$ \\
\hline (i & $6 \times 12$ & 605 & 6.02 & ed \\
\hline II & $9 \times 9$ & 538 & 7.05 & c d \\
\hline 1 & $9 \times 12$ & 403 & 5.03 & c d \\
\hline $\mathbf{J}$ & $12 \times 12$ & 302 & 3.40 & $d$ \\
\hline
\end{tabular}

1 Differences between treatments with same lelter or set of Jetters are not statistically significant at the 5-percent level.

of trees per unit-area, but $\mathrm{B}$ significantly outyiclded treatment A. The same condition occurred in treatments $\mathrm{D}$ and $\mathrm{E}$. Both treatments had the same number of trees per unit nea, but trealment E significantly outyielded treatment $\mathrm{D}$. Whether the differences can be attributed to competition for sunlight, efficiency in fertilizer absorption, or reduction of competition from weeds must be explored in future research along this linc.

Corrclation studies on the efficiency of cofice picking during the last crop did not show any detrimental effect of the diflerent planting distances. Apparently, the increase in yicld per unit-area in close-planted coffec compensates, to a certain degree, the difficulties inherent to the picking operation under such conditions. Moreover, the distances that the picker hat it cover at close planting distauces are reduced to a mininum.

From the practical point of view, the farmer should start his new plantings at a distance of $3 \times 6$ feet, specifically with Bourbon coffee. If 
after two or three crops he finds that the trees are too chese and intertere with farm practices, he can reduce the tree population to hall its original. Still, the farmer will be able to obtain good yields without an increase in cost of production.

\section{SUMMARY}

An experiment was performed at the Coffee Substation Farm, Adjuntas, P.R., in an Alonso clay. The population per unit area varied from a maximum of 2,419 trees per acre a minimum of 302 . Results after 7 years proved that the best planting distance was $3 \times 6$ feet. This treatment was followed in value by $3 \times 3 \times 9$ feet (louble hedge), and $3 \times 9$ and $6 \times 6$ foet. The reduction in yield of trees at further planting distances cannot be attributed exclusively to a decrease in plant population, since treatments with the same number of trees per acre differed in their yields. Correlation studies during the seventh srop did not show any effect of planting distance on the efficiency of picking.

\section{RESUMLN}

En la Subestación de Café en Adjuntas, P.R., se llevó a cabo un expcrimento con café en un suelo Alonso. Se hicieron siembras de arbustos de calé a distintas distancias sembrándose hasta un máximo de 2,419 arbustos y un míuimo de 302, por acre. Los resultados demostraron que la distancia más adecuada fue de 3 pies entre arbustos y 6 entre hileras. A esta prueba siguieron otras con las siguientes distancias: $3 \times 3 \times 9$ pies (barrera doble), $3 \times 9$ y $6 \times 6$ pies.

Los estudios de correlación que se hicieron durante la séptima cosecha demostraron que las distintas distancias de siembra no dificultaron en modo alguno la recolección.

\section{LITERATURE CITED}

1. Beatumont, J. I. and Fukunaga, E. T., Factors affecting the growth and yicld of coffere in Kona, Hawaii, Hawaii Agr. Pxp. Sta. Bull. 113, 39 pr., $19 \% 5$.

2. Capó, B. C., A new mothod of pertorming field trials, J. Agr. Irive. P. R. 28 (1): $22-34,1944$.

3. Medina, Artur Rocha de, Sistema de planta cao; número de cafeirus eon cada cova c número de hastas en cada eaferio, Rev. de Cafe, Porlugues, f (16): 16-24, 1957.

4. Wellman, F. J., Coflee, chap. $\mathrm{X}$, pp. 169 91, Interscience Publishers, Inc., New York, N.Y. 